\title{
ソフトコンピューティング手法を用いた曲 印象からの楽曲自動生成システムの構築门
}

\author{
秋口 俊輔 *
}

自動的な楽曲の生成という概念の歴史は古く, 乱数の偶然性を利用したものでは18世紀のモーツァルト による「音楽のサイコロ遊び」にまで遡る。これは，あらかじめ複数のフレーズを用意して扰き，サイコロ を転がすたびに出た目のフレーズを曲に付け加えていき，作曲をするものであった．現代においても，1957 年イリノイ大学に導入された初期のコンピュータ「ILLIAC・I」を使った「弦楽四重奏のためのイリアック組 曲」以降, 様々な研究がなされ, 多くの楽曲が作られてきた。しかしながら, 人間の感性, 特に各個人の感 性を反映させた楽曲生成システムは未だ研究の途上にあり，様々な研究機関で開発が続けられている。代 表的なものには, 言葉の印象から楽曲構造を導き出し作曲するシステムや, 対話型遺伝的アルゴリズムを 利用したシステムが研究されている。本研究では人間の感性と楽曲構造の関係を可変化することによって 各個人の感性に対応するシステムの構築を目指す，今回は，楽曲の印象を決定する曲全体の構造を数值化 し, この楽曲構造要素と各個人の感性との関係をニューラルネットワークによってモデル化するという手 法から，個人の感性を反映させた自動楽曲生成システムの構築を実現する。まず，楽曲の印象を決定する 曲全体の構造を,「楽曲はリズム, メロディ, ハーモニーの三要素からなる」との考えをもとに, 調, 和声, 旋律, 音高, リズム, テンポなどの楽曲構造要素として数值化を行う。 そして, 楽曲と楽曲から感じられ る印象との関係を, 楽曲を数值的に表現した楽曲構造要素と印象をSD法により数值化した印象語対との関 係に置き換えることで，ニューラルネットワークを用いて楽曲と楽曲から得られる曲印象との関係を学習 する。次に, 学習によって獲得された楽曲と曲印象との関係を利用し, 逆方向, すなわち入力する印象の 度合いに対応した楽曲構造要素を遺伝的アルゴリズムを用いて獲得する。これは楽曲構造要素を遺伝的ア ルゴリズムの個体とすることで学習済みニューラルネットワークの入力とし, 入力楽曲の曲印象值が出力 される。ここで得られた曲印象值と，作成したい曲印象值との差を評価関数として学習することで，印象 に対応した楽曲が自動的に生成される。

キーワード：ソフトコンピューティング，楽曲自動生成システム，人間共生システム

\section{1. はじめに}

自動的な楽曲の生成という概念の歴史は古く, 乱数 の偶然性を利用したものでは18世紀のモーツァルトに よる「音楽のサイコロ遊び」にまで遡る。これは，あら かじめ複数のフレーズを用意しておき，サイコロを転 がすたびに出た目のフレーズを曲に付け加えていき， 作曲をするものであった．現代においても，1957年イ リノイ大学に導入された初期のコンピュータ「ILLIAC ・ I」を使った「弦楽四重奏のためのイリアック組曲」[1] 以降, 様々な研究がなされ, 多くの楽曲が作られてき た。

その中には, ペンタブレットによって描かれた線の 座標と長さを，音源の音程と持続時間へと変換するこ とで発音するものや $[2]$, フラクタル図形であるマン

\footnotetext{
$\dagger$ Development of Melody Automatic Generation System from Music Impression Using Soft-Computing Method Shunsuke AKIGUCHI

* 富山商船高等専門学校

Toyama National College of Maritime Technology
}

デルブロ集合を用いてサウンドを生成するマンデルブ 口音楽[3]といった, グラフィックスを音に対応させ る研究や, カオス理論を応用したコンピュータミュー ジックとして，ロジスティック写像によって発生され るメロディに様々な音楽的フィルタを適用したサウン ドを生成する研究 [4], さらにはカオス理論を応用し て作成したサウンドとグラフィックスを組み合わせる ことによって, 聴覚的・視覚的効果を人間に与えるこ とを目標とした研究も行われている[5].

しかしながら, 人間の感性, 特に各個人の感性を反 映させた楽曲生成システムは未だ研究の途上にあり, 様々な研究機関で開発が続けられている。人間の感性 を反映させた楽曲生成の分野では, 人間の評価を遺伝 的アルゴリズムの進化の過程に組み込み，人間の主観 に対応した遺伝的操作を行う対話型遺伝的アルゴリズ ムが比較的よく用いられる。このような対話型遺伝的 アルゴリズムを用いた手法として，作曲打よび即興演 奏エージェントを設計し, コンピュータと人間のジャ ズセッションを行うものや [6], 対話型遺伝的アルゴ 
リズムの一種である模擬育種法を用いて音楽のフレー ズを進化させる試み[7], ユーザのイメージを反映さ せたメロディーラインを生成するシステムの構築など の研究 $[8]$ が行われている。また対話型遺伝的アルゴ リズムを用いたもの以外にも，言葉やメディアデータ 間などの意味的な関係を与えられた文脈や状況に応じ て動的に計算することが可能である意味の数学モデル を用いることにより，任意の言葉からの楽曲自動生成 を実現する研究も行われている $[9]$.

これらの研究によって生成された楽曲はどれも興味 深く, 音楽の専門知識がなくとも, 楽曲を視聴して感 じたイメージを評価に反映させたり，用意された印象 語を用いることで，感性に沿った楽曲を自動的に生成 することができる。しかしながら, 対話型遺伝的アル ゴリズムを用いた場合, 楽曲生成の度に人間が評価を 行わねばならず, 印象語を用いた場合は各個人の感性 に的確に沿うことは難しい.

本研究では人間の感性と楽曲構造の関係を可変化す ることによって各個人の感性に対応するシステムの構 築を目指す。今回は, 楽曲の印象を決定する曲全体の 構造を数值化し，この構造と各個人の感性との関係を ニューラルネットワークによってモデル化するという 手法から，個人の感性を反映させた楽曲自動生成シス テムの構築を実現する。

\section{2. 楽曲自動生成システム}

ここでは楽曲自動生成システムの処理の流れと, 楽 曲構造要素の定義・作曲時の利用方法の概要について 述べる。また，曲印象の計測とニューラルネットワー クを用いた楽曲構造要素に対応した曲印象の学習手法 についても述べる。

本研究では楽曲の自動生成に関して, まず最初に各 個人がどのような楽曲からどのような印象を受けるか について, その関連性を見出す。どのような楽曲であ るかについては, 楽曲を後述する楽曲構造要素として 分解し, 数值化を行う。また, どのような印象を受け るかについては印象語対とSD法を用い，受ける印象 を数值化する。このように 1 つの楽曲を楽曲構造要素 と印象值という異なる観点から観察し, 楽曲構造要素 を入力, 印象值を出力としたニューラルネットワーク を用いて, どのような楽曲構造要素がどのような印象 值となるかについて学習を行う。これにより，楽曲が 人間に与えるであろう印象を推測することができる.

次に, 楽しそうな楽曲, さみしそうな楽曲といっ た，作成したい楽曲のイメージを印象值として入力 し，それに沿うような楽曲を遺伝的アルゴリズムを用 いて作成する。遺伝的アルゴリズムの個体を楽曲構造
要素とし, ランダムに生成された各個体を上述の学習 済みニューラルネットワークの入力とする。これまで の学習により獲得された楽曲構造要素と印象值との関 連性を基に, 入力された楽曲構造要素が与えるであろ う印象が出力される。本研究では, 二ューラルネット ワークの出力值と, 作成したい楽曲のイメージである 印象值とを比較し, これらの誤差を遺伝的アルゴリズ ムの適応度とすることで, 䛊差が小さくなるように遺 伝的アルゴリズムの学習を行い, 最終的に誤差が一番 小さくなった楽曲構造要素で構成される個体から，楽 曲を生成する。このような手順により, 個人の感性に 反映した楽曲を自動的に生成する。次節からはより具 体的な項目について説明する。

\section{1 楽曲生成の流れ}

図 1 は今回提案する楽曲自動生成システムの処理の 流れである。西洋音楽の世界では,「楽曲はリズム, メロディ, ハーモニーの三要素からなる」と考えられ ており [10], 本システムにおいてもこれに準じて, 楽 曲を 3 つの部位に分けて別々に生成する。楽曲構造要 素の決定方法については後述し，ここでは各要素の定 義についてのみ触れる。また, 以降これら 3 つを総称 して楽曲の三要素と呼称する。

\section{1 .1 楽曲構造要素の定義}

音楽心理学者Hevnerは音楽の構成要素として調 (長 調 $/$ 短調), 旋律 (上昇 /下降), 音高 (高/低), 和声 (単純 /複雑), テンポ, リズム (固定／流動)の6つを 定義している $[11,12,13]$. 本研究ではこの定義に 基づき, 以下の 5 系統 40 項目にテンポを加えた計 41 項目を楽曲構造要素として音楽を数值化する.

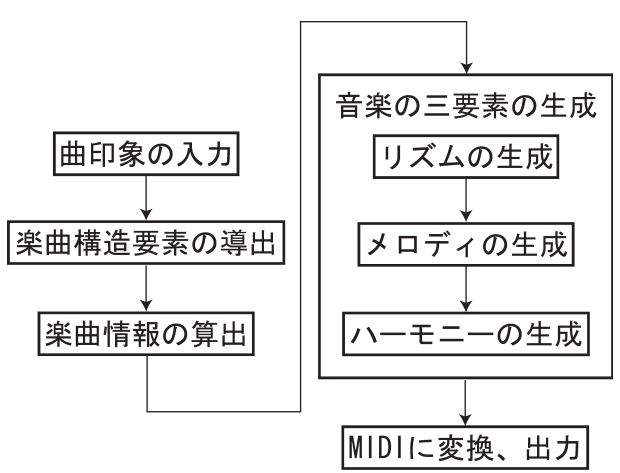

図 1 楽曲生成の流れ 
- 調

$\mathrm{C}, \mathrm{C}+, \mathrm{D}, \mathrm{D}+, \mathrm{E}, \mathrm{F}, \mathrm{F}+, \mathrm{G}, \mathrm{G}+, \mathrm{A}, \mathrm{A}+$,

$\mathrm{B}$, 長調, 短調

- 和声

2 和音, 3 和音, 4 和音それぞれの割合, 音符長 平均, 音符長二乗平均

- 旋律

上昇音, 下降音, 水平音それぞれの割合, 音高平 均, 音高二乗平均

- 音高

音高平均, 音高二乗平均, 主音以上の高音の割 合, 主音未満の低音の割合

・リズム

2 分音符の割合, 付点 4 分音符の割合, 4 分音符 の割合, 8 分音符の割合

今回提案する楽曲自動生成システムで生成される楽 曲は図 2 のようにメロディ部分とハーモニー部分が明 確に分かれている。また, 文献[8]を参考に, 使用す る音符は「 2 分音符」,「付点 4 分音符」,「4 分音符」, $\lceil 8$ 分音符」の 4 種類に限定している. 本研究では, こ れらを利用して以下の定義・公式に基づき, 各楽曲構 造要素を算出・使用する。たたし，

- $n$ 番目のメロディの構成音の音高: Note $(n)$

- $n$ 番目のメロディの構成音の音符長 : Len $(n)$ ( 4 分音符の音符長を 1 とする)

・メロディの音符数 $: N$

- $n$ 番目の和音の構成音数: $\operatorname{Code}(n)$

- $n$ 番目の和音の音符長 : $C \operatorname{Len}(n)$

- ハーモニーの和音数 : $M$

・主音の音高：Note (0)

と定義する。主音 (中心音) とは音階の最初の音であ
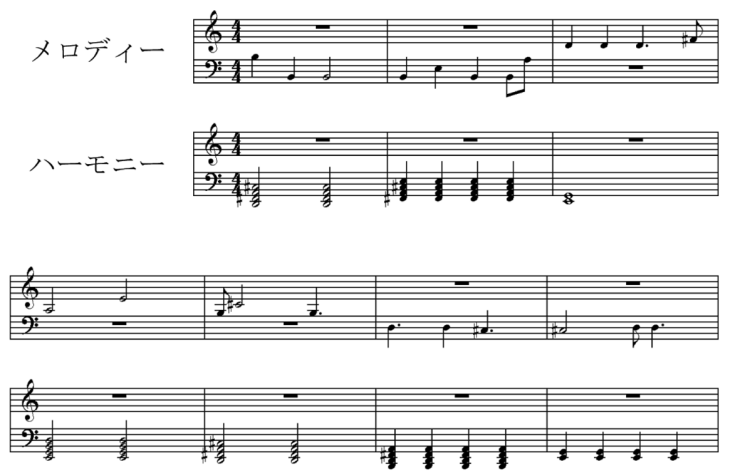

図 2 生成される楽曲の例
り, 主音で始まる楽曲や, 主音で終わる楽曲が多く存 在する [10]。そこで本研究では主音の音高を上記のよ うに定義する。

音高を表す数值はMIDIフォーマットに準じてお り, ピアノの中央のC $($ ド)を番号 60 として, 半音ごと に 1 つづ増減していき，一番低い音が 0 ，一番高い音

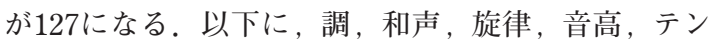
ポ，リズムについてそれぞれ説明する。

\subsection{2 調}

楽曲の調性を定義している。調性は楽曲の主音(中 心音) と構成音を決定する際に使用する。例えば，C と長調が 1 の場合は八長調, D と短調が 1 の場合は二 短調になる。

- C, C+, D, D+, E, F, F+, G, G+, A, A+, B 主音がどの音になるかを表す。必ずいずれか一つ が 1 となり, 残りの全てが 0 になる。

- 長調, 短調

長音階 (全音一全音一半音一全音一全音一全音一半 音の間隔で音が分布している音階), 短音階(全音 一半音一全音一全音一半音一全音一全音の間隔で音 が分布している音階)のいずれを使用するか表 す.

\subsection{3 和声}

ハーモニー(和声)がどのような和音によって構成さ れているかを表す。

2 和音の割合 $=\frac{\sum_{n=0}^{M-1} \delta(\operatorname{Code}(n)-2)}{M}$

2 和音の音符長平均 $=\frac{\sum_{n=0}^{M-1} C \operatorname{Len}(n) \delta(\operatorname{Code}(n)-2)}{M}$

2 和音の音符長二乗平均 $=\frac{\sum_{n=0}^{M-1} C \operatorname{Len}(n)^{2} \delta(\operatorname{Code}(n)-2)}{M}$

以下, 3 和音, 4 和音共に同様である。

\subsection{4 旋律}

メロディ(旋律)内で, どのような音の変化が起こる かを表す。式中に打いて, Note $(n+1)-$ Note $(n)=$ $\Delta$ Note $(n), \operatorname{Len}(n+1)-\operatorname{Len}(n)=\Delta \operatorname{Len}(n)$ であると する.

上昇音の割合 $=\frac{\sum_{n=0}^{N-1} H_{0}(\Delta N o t e(n))}{N}$ 
下降音の割合 $=\frac{\sum_{n=0}^{N-1}(1-U(\Delta N o t e(n)))}{N}$

水平音の割合 $=\frac{\sum_{n=0}^{N-1} \delta(\Delta N o t e(n))}{N}$

上昇音高平均 $=\frac{\sum_{n=0}^{N-1} H_{0}(\Delta N o t e(n)) \frac{\Delta N o t e(n)}{\Delta \operatorname{Len}(n)}}{\sum_{n=0}^{N-1} H_{0}(\Delta N o t e(n))}$

下降音高平均 $=\frac{\sum_{n=0}^{N-1}(1-U(\Delta N \text { ote }(n))) \frac{-\Delta N o t e(n)}{\Delta \operatorname{Len}(n)}}{\sum_{n=0}^{N-1}(1-U(\Delta N o t e(n)))}$

水平音高平均 $=\frac{\sum_{n=0}^{N-1} \delta(\Delta N o t e(n)) \operatorname{Note}(n)}{\sum_{n=0}^{N-1} \delta(\Delta N o t e(n))}$

$$
\text { 上昇音高二乗平均 }=\frac{\sum_{n=0}^{N-1} H_{0}(\Delta N o t e(n))\left(\frac{\Delta N o t e(n)}{\Delta \operatorname{Len}(n)}\right)^{2}}{\sum_{n=0}^{N-1} H_{0}(\Delta N o t e(n))}
$$

下降音高二乗平均 $=\frac{\sum_{n=0}^{N-1}(1-U(\Delta \operatorname{Note}(n)))\left(\frac{-\Delta \operatorname{Note}(n)}{\Delta \operatorname{Len}(n)}\right)^{2}}{\sum_{n=0}^{N-1}(1-U(\Delta \operatorname{Note}(n)))}$

水平音高二乗平均 $=\frac{\sum_{n=0}^{N-1} \delta(\Delta N o t e(n)) N o t e(n)^{2}}{\sum_{n=0}^{N-1} \delta(\Delta N o t e(n))}$

\section{1 .5 音高}

楽曲全体の音の高さと，その分布を表す。

音高平均 $=\frac{\sum_{n=0}^{N-1} \operatorname{Note}(n)}{N}$

音高二乗平均 $=\frac{\sum_{n=0}^{N-1} N \text { ote }(n)^{2}}{N}$

主音以上の高音の音符数の割合 $=\frac{\sum_{n=0}^{N-1} U(\operatorname{Note}(n)-\operatorname{Note}(0))}{N}$

主音未満の低音の音符数の割合 $=\frac{\sum_{n=0}^{N-1}(1-U(N o t e(n)-N o t e(0)))}{N}$

\subsection{6 テンポ}

一分間に含まれる拍の数を表す。通常MIDIフォー マットにおける一拍は 4 分音符 1 つ分の演奏時間に相 当する．拍をどのくらいの速さで打つのかを表し，楽 曲の速さを示す. 数值が大きいほど速く, 小さいほど 遅くなる。テンポの数值が 600 場合, 一分間に 4 分音 符を60回演奏できる.

\subsection{7 リズム}

メロディの中に含まれる音符の長さの割合を表す.

2 分音符の割合 $=\frac{\sum_{n=0}^{N-1} \delta(\operatorname{Len}(n)-2.0)}{N}$

付点 4 分音符の割合 $=\frac{\sum_{n=0}^{N-1} \delta(\operatorname{Len}(n)-1.5)}{N}$

4 分音符の割合 $=\frac{\sum_{n=0}^{N-1} \delta(\operatorname{Len}(n)-1.0)}{N}$

8 分音符の割合 $=\frac{\sum_{n=0}^{N-1} \delta(\operatorname{Len}(n)-0.5)}{N}$

\section{2 楽曲構造要素からの楽曲固有情報の取得}

リズム, メロディ, ハーモニーの「楽曲の三要素」以 外にも, 楽曲には様々な情報が存在している。ここで は, 楽曲生成に使用する「主音 (中心音)」と「曲の長さ (小節数)」を楽曲構造要素から求める方法について述 ベる.

\subsection{1 主音(中心音)}

主音とは音階の最初の音のことであり, 調性のある 楽曲では, この音に帰着しようとする力が働く.今回 は楽曲構造要素の調のカテゴリから音階を導き出し, 音高のカテゴリ内の平均音高と併用して主音の音高を 決定する。これにより2.1.1節におけるNote (0) が決定 される。

主音の音高は

$(60+K e y)+N * 12(0<=N<=10)$

で表現することができる候補のうち, 最も平均音高に 近いものを使用する。ここで, Keyは使用する調に よって表 1 に準じて決定する.

表 1 調の対応

\begin{tabular}{|c|c||c|c||c|c||c|c|}
\hline $\mathrm{C}$ & 0 & $\mathrm{C}+$ & 1 & $\mathrm{D}$ & 2 & $\mathrm{D}+$ & 3 \\
\hline $\mathrm{E}$ & 4 & $\mathrm{~F}$ & 5 & $\mathrm{~F}+$ & 6 & $\mathrm{G}$ & 7 \\
\hline $\mathrm{G}+$ & 8 & $\mathrm{~A}$ & 9 & $\mathrm{~A}+$ & 10 & $\mathrm{~B}$ & 11 \\
\hline
\end{tabular}

\subsection{2 曲の長さ (小節数)}

曲の長さには 2 種類の意味が存在する。一つは楽曲 の演奏時間であり，もう一つは楽曲に含まれる小節の 数である. 演奏時間は通常, 分単位もしくは秒単位で 表現される。演奏時間と楽曲のテンポが一定で決まっ ている場合, この二つの情報から楽曲内の小節数は式 (22)で算出できる.

小節数 $=\frac{25 * \text { Time }}{\text { Tempo }}$ 
ここで, Timeは演奏時間[秒], Tempoは楽曲のテン ポ[ 4 分音符/分]である.

Time, Tempoの值によるが, 式(22) は実数解にな ることが予測される，关の場合，本研究では小数点以 下切り捨てとして, 楽曲に含まれる小節数を決定して いる。

\section{3 音楽の三要素の生成}

前述のように「楽曲はリズム, メロディ, 八ーモ ニーの三要素からなる」と考えられており, 今回提案 するシステムでも，これに準じて楽曲の生成を行う。 今回は各要素を異なった遺伝子型で表現し, 遺伝的ア ルゴリズムを使用して解探索を行う。遺伝的アルゴリ ズムの評価関数は各要素から算出した楽曲構造要素と 作曲したい曲の楽曲構造要素の差を取るものとする. 音楽の三要素はそれぞれ異なる楽曲構造要素の系統と 対応しており, 実際に各要素で差を取るのは対応して いる系統のみである。

以下に, 各要素の遺伝子型と対応する楽曲構造要素 の系統を記す。

・リズム

一染色体

一小節ごとの音の並びとし，「2 分音符」「付点 4 分音符 $「 4$ 分音符」「 8 分音符」の 4 種類の及 を使用するため，一小節内で表現できる音の並 びは全108種類となる。一つの染色体はこのい ずれを使用するかを表している.

一個体の長さ

楽曲に含まれる小節の数であり, 式(22)から算 出する.

一対応する楽曲構造要素：リズム

・メロディ

一染色体

音符の度数であり, 主音を中心に士VII度まで (-7〜+6の間で值を設定する) とする。ただし 最初の音符は主音になるので常に0である.

一個体の長さ

楽曲に含まれる音符の数であり, リズムの生成 で決定された音符数から個体の長さが決まる.

一対応する楽曲構造要素 : 旋律, 音高

・ハーモニー

一染色体

小節内で同時に演奏される和音の数と長さとす る. 長さは「全音符」「 2 分音符 $「 4$ 分音符」「 8 分音符」の中から選ばれ, 全音符の場合は 1 回, 2 分音符の場合は 2 回, 4 分音符の場合は
4 回, 8 分音符の場合は 8 回，1 小節中に同じ 和音を演奏する

一個体の長さ

楽曲に含まれる小節の数. 式22から算出する.

一対応する楽曲構造要素 : 和声

本研究では, 遺伝的アルゴリズムで生成される染色 体について, 生成できる全範囲から一様にランダムで 初期個体を生成し, 個体数 100 , 交叉率 $70 \%$, 突然变 異率 $3 \%$ として，学習を行った。

\section{3．曲印象の計測と学習手法}

今回提案する楽曲自動生成システムでは, 人間の感 性を楽曲生成に反映させるため, 楽曲の生成とは別 に，まず利用者の感性情報を入力する必要がある。今 回はシステム側で用意したサンプル曲に対して, 利用 者がその曲から受ける印象を, 表示される曲印象語の 度合いとして $-3 \sim+3$ の 7 段階で入力する。

\section{1 曲印象語の定義}

今回は入力する印象語として表 2 の 8 組の印象語対 を使用した。この印象語は文献[14]に扔いて，「音楽 に対しての情動的評価尺度項目」として使われた表 3 の64の形容詞のうち, 反対語大辞典[15]によって対義 語を断定することができた表 4 の23項目を使用し， ニューラルネットワークに学習させた場合の未知曲に 対する正答率が高かった項目を選択・使用している.

表 2 曲印象語

\begin{tabular}{|c|c|c||c|c|c|}
\hline 美しい & $\leftrightarrow$ & 醜い & 軽い & $\leftrightarrow$ & 重い \\
\hline 騒がしい & $\leftrightarrow$ & 静かな & にぎやかな & $\leftrightarrow$ & さびしい \\
\hline 明るい & $\leftrightarrow$ & 暗い & 陽気な & $\leftrightarrow$ & 陰気な \\
\hline うれしい & $\leftrightarrow$ & かなしい & ゆるんだ & $\leftrightarrow$ & はりつめた \\
\hline
\end{tabular}

表 3 情動的評価尺度項目 (文献[14]より参照)

\begin{tabular}{|c|c|c|c|}
\hline 快い弛緩 & 陽気さ & 抑欌 & 緊張 - 力動性 \\
\hline あたたかい & 明るい & 陰気な & 勇ましい \\
\hline 安定した & あっさりした & 悲しい & 緊張した \\
\hline 美しい & 生き生きした & 暗い & 好き \\
\hline おだやかな & うきうきした & さびしい & 力強い \\
\hline おちついた & うれしい & 地味な & 激しい \\
\hline 静かな & おもしろい & 冷たい & はりつめた \\
\hline 素朴な & 軽い & 濁った & \\
\hline なめらかな & 元気な & にぶい & \\
\hline のどかな & さっぱりした & ゆううつな & \\
\hline のんびりした & 楽しい & & \\
\hline 優しい & にぎやかな & & \\
\hline やわらかい & ユーモラスな & & \\
\hline 優雅な & 陽気な & & \\
\hline ゆったりした & & & \\
\hline
\end{tabular}


表 4 初期段階における曲印象語対

\begin{tabular}{|c|c|c|}
\hline あたたかい & $\leftrightarrow$ & つめたい \\
\hline うきうきした & $\leftrightarrow$ & しんみり \\
\hline 安定した & $\leftrightarrow$ & 動摇した \\
\hline うれしい & $\leftrightarrow$ & かなしい \\
\hline 美しい & $\leftrightarrow$ & 醜い \\
\hline 軽い & $\leftrightarrow$ & 重い \\
\hline 抗だやかな & $\leftrightarrow$ & 激しい \\
\hline 元気な & $\leftrightarrow$ & ぐったりした \\
\hline おちついた & $\leftrightarrow$ & うわついた \\
\hline 楽しい & $\leftrightarrow$ & 苦しい \\
\hline 静かな & $\leftrightarrow$ & 騒がしい \\
\hline にぎやかな & $\leftrightarrow$ & さびしい \\
\hline なめらかな & $\leftrightarrow$ & あらい \\
\hline 陽気な & $\leftrightarrow$ & 陰気な \\
\hline 優しい & $\leftrightarrow$ & きびしい \\
\hline 地味な & $\leftrightarrow$ & 派手な \\
\hline やわらかい & $\leftrightarrow$ & かたい \\
\hline 濁った & $\leftrightarrow$ & 澄んだ \\
\hline 優雅な & $\leftrightarrow$ & 粗野な \\
\hline 勇ましい & $\leftrightarrow$ & いくじない \\
\hline 明るい & $\leftrightarrow$ & 暗い \\
\hline はりつめた & $\leftrightarrow$ & ゆるんだ \\
\hline あっさりした & $\leftrightarrow$ & こってり \\
\hline
\end{tabular}

\section{2 曲印象の計測}

曲印象と楽曲構造要素の関係をニューラルネット ワークによってモデル化するために，ニューラルネッ トワークの教師信号として使用する曲印象を計測し た。曲印象の計測はSD法を用いて，対象となる楽曲 を聴きながら，各項目 (印象語対)に数值を入力する. 作成した入力画面は四 3 のようになっており，各項目 のスライダーコントロールを左右に動かし， $-3 \sim+3$ までの 7 段階で楽曲の印象を入力する。ここで，「美 しい」や「嬉しい」などのポジティブな印象語の場合は 正の值に，「醜い」や「寂しい」などのネガティブな印象

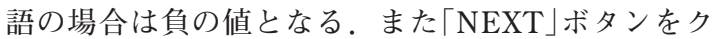
リックすることで, 現在の入力情報が記録され，次の 楽曲の演奏が開始される。途中で中断した場合も，現

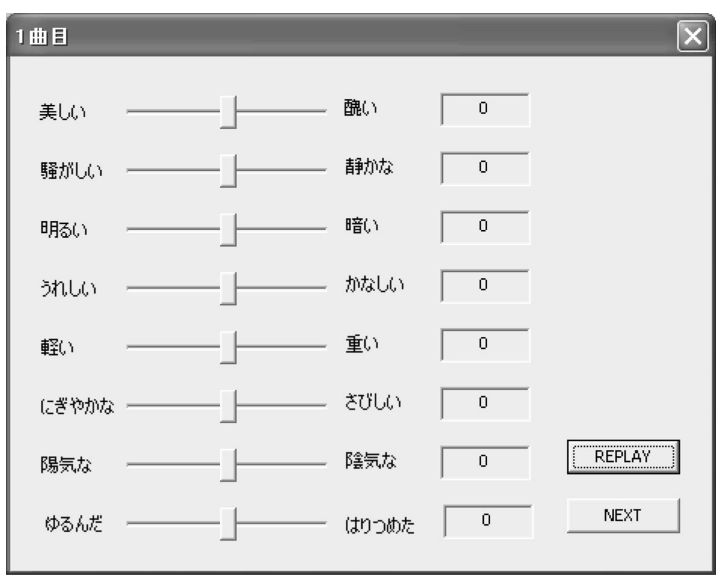

図 3 曲印象の入力画面
在入力中の楽曲から演奏が再開される.

計測用の練習曲として前述の楽曲生成システムを用 いて120曲を生成・使用した。この120曲のうち，実 際に教師信号として使用するのは100曲のみであり， 残りの 20 曲はニューラルネットワークの性能評価のた めの未知曲として使用する。尚, 楽曲を生成する際に 使用する楽曲構造要素は乱数を用いて決定した。

\section{3 ニューラルネットワークの学習}

ここでは, 以下の設定でニューラルネットワークの 学習を行う。

表 5 ニューラルネットワークの構造

\begin{tabular}{|c|c|}
\hline 入力信号 & 楽曲構造要素（41 項目） \\
\hline 中間層 & $40-20$ \\
\hline 教師信号 & 曲印象（8 項目） \\
\hline 終了判定 & 全ての | 教師信号 - 出力信号 $\mid<0.10$ \\
\hline
\end{tabular}

曲印象の計測を行った 120 曲中 100 曲を学習曲とし て使用し, 各楽曲の楽曲構造要素からどのような曲の 印象を受けるかについて学習する。これは同じ曲印象 を受ける楽曲構造要素は一つではない, つまり楽曲構 造要素：曲印象＝多：19関係にあると考えられるた めである。さらに, 曲印象を計測した残り 20 曲を未知 曲として使用し，学習済みのニューラルネットワーク に楽曲構造要素を入力した場合の曲印象と実際に計測 した曲印象の間にどの程度の誤差が生じるかについて の実験を行った。実験の結果, 平均誤差は 0.93 とな り, 図 3 の入力画面で, およそ 1 目盛り分程度の誤差 となった。しかし, 項目によっては 3 以上の誤差が出 ているものもあり，この点に関しては印象語や楽曲構 造要素の設定を見直す必要があると考えられる。

\section{4 曲印象からの楽曲構造要素の算出}

本研究で提案する楽曲生成システムは生成楽曲の曲 印象を入力することで, 楽曲構造要素を算出し, それ に沿った楽曲を生成する。しかし，前項で述べたよう に本研究で使用するニューラルネットワークは楽曲構 造要素から曲印象の導出を行うことはできるが，その 逆の導出は行うことができない。これは前述のように 同じ曲印象を受ける楽曲構造要素は一つではないため である。

そこで, 本研究では楽曲構造要素を染色体とした, 遺伝的アルゴリズムによって曲印象に最も一致した楽 曲構造要素を導出する。これは遺伝的アルゴリズムの 偶然性を利用して最適解と考えられる複数の解のうち 一つを選ぶためであり，この楽曲構造要素の導出に 限っては十分最適解に近いのであれば, ローカルミニ 
マムも一つの解であると考える。この遺伝的アルゴリ ズムの遺伝子型は, 染色体は楽曲構造要素となり, 評 価関数はニューラルネットワークに個体を入力した場 合の出力と生成したい楽曲の曲印象の差となる.

\section{5 自動作曲シミュレーション}

本研究で制作した楽曲自動生成システムを用いて, どれだけ人間の感性に沿った楽曲を生成することがで きるかについて実験を行った，全 3 曲生成し，入力曲 印象と実際に生成された楽曲の聴取実験を行った曲印 象との誤差を取得する。楽曲生成画面は図 4 のように なっている。ここで, 図 4 の「楽曲構造要素段階」は 図 1 に打ける「楽曲構造要素の導出」で設定された楽曲 構造要素を,「生成曲印象 (予想)」は実際に生成された 楽曲の楽曲構造要素をニューラルネットワークに入力 した場合の出力(曲印象)を表している。

入力する曲印象は乱数を使用して, 全 3 曲, 各曲 8 項目の印象語にそれぞれ数值を割り当てる. 各曲印象 を表す数值は, $-3 \sim+3$ までの 7 段階で入力し, 表 6 のようになっている.

表 6 の曲印象を実際に楽曲生成システムに入力する ことで生成された楽曲について, 再度評価を行った印 象をまとめたものを表 7 に示す。また，参考のために 1 番目の生成楽曲の譜面を図 5 示す。この図に扔い て，Mはメロディー，Hは八ーモニーの譜面である.

さらに, 作成したい楽曲の印象值を入力し, 出力さ れた楽曲について，どのような印象を受けるかについ ての評価を行った，評価方法としては，まず 5 人の被 験者に 3 曲ずつ楽曲を作成してもらった。この生成さ れた楽曲の他に, 乱数によって決定した楽曲構造要素 を基に生成した 7 曲を加え, 計 10 個の楽曲を順不同で 聴いてもらい，再度印象評価を行った，先に生成した 3 曲は生成された時点では被験者に聴かせていない. この評価結果から，被験者が作成した 3 曲の評価值を 抜き出し， 3 曲の楽曲を生成する際に入力した印象值 と, 再度行った印象評価の結果との平均誤差について まとめたものを表 8 に示す.

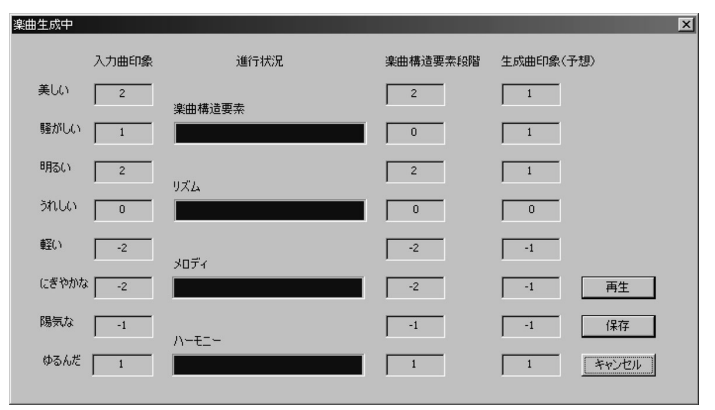

図 4 楽曲生成画面
表 6 入力曲印象

\begin{tabular}{|c||c|c|c|}
\hline & 1 & 2 & 3 \\
\hline \hline 美しい & -1 & 0 & 1 \\
\hline 騒がしい & 1 & -2 & -1 \\
\hline 明るい & -2 & -3 & -1 \\
\hline うれしい & -3 & 2 & 2 \\
\hline 軽い & 1 & -1 & 1 \\
\hline にぎやかな & 2 & -2 & 0 \\
\hline 陽気な & 1 & 3 & 0 \\
\hline ゆるんだ & -3 & 1 & 2 \\
\hline
\end{tabular}

表 7 生成楽曲曲印象

\begin{tabular}{|c||c|c|c|}
\hline & 1 & 2 & 3 \\
\hline \hline 美しい & -2 & 1 & -1 \\
\hline 騒がしい & 2 & -2 & 0 \\
\hline 明るい & -3 & -2 & -1 \\
\hline うれしい & -3 & 2 & 1 \\
\hline 軽い & 2 & -2 & 1 \\
\hline にぎやかな & 1 & 2 & 1 \\
\hline 陽気な & 2 & 2 & 0 \\
\hline ゆるんだ & -3 & 2 & 3 \\
\hline
\end{tabular}

$\mathrm{M}$

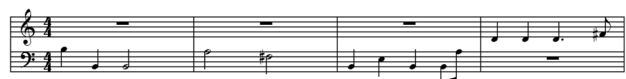

$\mathrm{H}$

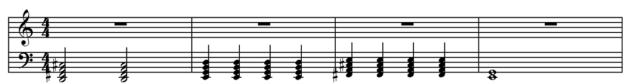

$\mathrm{M}$

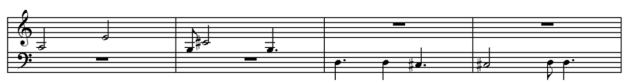

$\mathrm{H}$
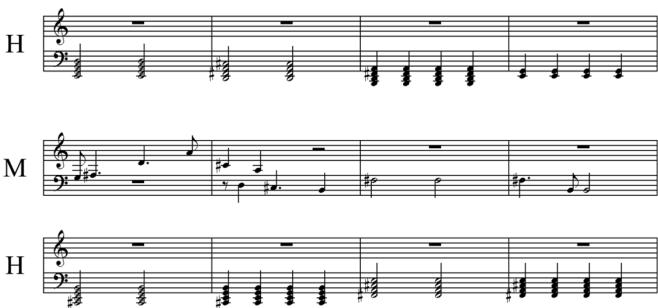

M

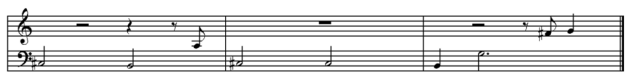

$\mathrm{H}$

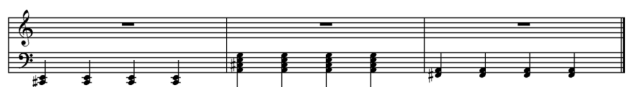

図 5 生成楽曲例

表 8 生成楽曲の再評価

\begin{tabular}{|c||c|c|c|c|c|c|}
\hline & 1 & 2 & 3 & 4 & 5 & 平均誤差 \\
\hline \hline 美しい & 0.67 & 1.00 & 0.67 & 0.67 & 0.33 & 0.67 \\
\hline 騒がしい & 1.67 & 1.33 & 1.33 & 1.67 & 1.67 & 1.53 \\
\hline 明るい & 1.00 & 1.33 & 1.33 & 1.00 & 1.00 & 1.13 \\
\hline うれしい & 0.67 & 1.00 & 1.00 & 0.67 & 0.33 & 0.73 \\
\hline 軽い & 0.33 & 0.67 & 0.00 & 0.33 & 0.33 & 0.33 \\
\hline にぎやかな & 2.00 & 1.67 & 1.33 & 1.33 & 2.00 & 1.67 \\
\hline 陽気な & 0.67 & 1.00 & 1.33 & 1.67 & 1.67 & 1.27 \\
\hline ゆるんだ & 0.67 & 0.67 & 1.00 & 0.67 & 0.67 & 0.73 \\
\hline 平均 & 0.96 & 1.08 & 1.00 & 1.00 & 1.00 & 1.01 \\
\hline
\end{tabular}




\section{4. 考察}

表 6,7 から，「入力された曲印象」と「生成楽曲の 曲印象」の間に誤差が 0.86 , 入力画面の扎よそ 1 目盛 り分に収まっていることがわかる。これは，その場の 䨌囲気や環境，気分などによって生じる䛊差(環境誤 差)の範疇だと考えられる。実際に聞いてみた曲の印 象も, 入力曲印象に近い䨌囲気が出ていたように感じ られた。しかしながら, 表に示したもの以外にもいく つか楽曲生成を行ったが, 楽曲によっては平均 2 以上 の䛊差を算出して打り, 印象語によっては最大で 4 の 誤差が生じているものもある。これは，実際に作りた かった印象と真逆の曲印象であると言え, 環境䛊差で は説明がつかない.

これは楽曲構造要素の「二乗平均」の項目が含まれて いる事が原因の 1 つとして考えられる. 各数值のばら つき具合を設定するために設けた項目だが，同系統の 「平均」と干渉し合い,「音楽の三要素」を生成する段階 で評価関数を一定方向に定め切れていない可能性があ る。これによって, 楽曲の生成に大きな䛊差が生じて いると考えられる.

表 8 において, 各被験者ごとの平均䛊差は 1 程度と なって打り，比較的作成者の感性を反映した楽曲が生 成できたと考えられる。しかしながら，「騒がしい」, 「明るい」,「にぎやかな」,「陽気な」の項目の䛊差が他 の項目よりも大きい，これは生成された楽曲を再度評 価する際に，「騒がしい」と「にぎやかな」，「明るい」と 「陽気な」がそれぞれ分類し難いためと考えられる。例 えば，「騒がしい」の值が大きい楽曲は，「にぎやかな」 の値が大きい楽曲に比べ, 曲調は類似しているが, 使 用される音の高さが平均的に低い楽曲となることが多 かった。これら 2 つ楽曲を聴き比べれば違いが分か るが, 個別に聴くと曲調が類似しているため, 判別し 難い。これについては, 使用する印象語対を再検討す る必要があると考えられる。

また, 楽曲構造要素や曲印象の決定について, 特に 楽曲構造要素は曲印象を判別するために必要な情報で あり, 人間がどの程度音楽を細分化して認識している かを表す指標とも言える. 今回提案した楽曲構造要素 は文献[2]で使用されていた項目に独自で追加した 41 項目であるが, 被験者によってはこれ以外の項目から 曲の印象を感じ取っている可能性もある。また, 逆に 不必要な項目が含まれているために, 正確に曲印象を 導出できていない場合も考えられる.

\section{5 . まとめ}

本研究では, 楽曲の印象を決定する曲全体の構造を 数值化し, この構造と各個人の感性との関係をニュー ラルネットワークによってモデル化するという手法か ら, 個人の感性を反映させた自動楽曲生成システムを 提案した。ささら, 遺伝的アルゴリズムを使用し, 数 值化した曲構造(楽曲構造要素)から実際の音楽(楽譜) を生成することを可能とした，楽曲の自動生成に関す る研究は多く存在するが, 本手法のようにニューラル ネットワークと遺伝的アルゴリズムを併用した手法は あまり研究されていない。

聴取実験の結果, 入力曲印象と生成楽曲の曲印象が 類似したものになり，感性を反映した楽曲の生成が可 能であることが確認できた。しかし，一部の楽曲生成 では曲印象に䛊差が生じて打り, 楽曲構造要素の設定 に疑問が残る結果となった。特に各項目の二乗平均に ついては再考の余地があると思われる。また, 曲印象 入力画面についても, 矢の場の環境などによって生じ る誤差を極力小さくし， かつ言葉に対する印象を一定 方向に位置づけられるような方式を考案する必要があ る. 改良案として, 現在入力を SD法を利用した数值 入力で行っているのに対して, 色や絵, 音などの視 覚・聴覚情報を用いた入力方式を導入する事も考えら れる。

本研究では入力に用いる印象語の選定を行った。こ れは印象語の数が多すぎると入力に手間がかかるため に行ったが, 楽曲の印象を適切に表現するために必要 な印象語がそもそも不確定であったため, 今回は未知 曲に対する正答率が高い項目を8つ選んで使用した。 これは未知曲に対する正答率が高い項目が楽曲の印象 を適切に表現するために必要であろうという考えのも とに行った。このような考えによって選んだ印象語 は, 楽曲印象を少ない項目で表現できる可能性がある と考えられるが, 今後因子分析などの解析手法を用い た印象語の選定を行い, 両者で比較を行う必要がある と考えられる。

\section{参 考 文 献}

[ 1 ] L.Hiller, L.Isaacson, "Experimental Music", MacGrawHill, 1959

[ 2] G.Marino, M.Serra, J.Raczinski, "The UPIC System : Origins and Innovations", Perspectives of New Music, Vol.31, No.1, pp.258-269, 1993

[ 3 ] 尾上文男, “Mandelbrot Set, Chaos, Fractal”, http://members.jcom.home.ne.jp/onoue/

[ 4 ] 長嶋洋一, “Chaos 理論とComputer Music”, 京都芸 術短期大学紀要 [瓜生], Vol.16, pp.28-44, 1993

［5］前田陽一郎, 丹羽俊明, 山本昌幸, “大域結合写像に 
よるインタラクティブカオティックサウンド生成シス テム抢よび音楽的要素の導入”, 知能と情報 (日本知 能情報ファジィ学会誌), Vol.18, No.4, pp.507-518, 2006

[6 ] J.A.Biles, "GenJam : A genetic algorithm for generating jazz solos, " in Int. Computer Music Conf. (ICMC'94), (Aarhus, Denmark), pp.131-137, 1994.

～ 7 ] 欯見達夫, 中田詠一, “模擬育種法に基づく作曲支援 システムの試み”, 計測自動制御学会第 28 回 知能シ ステムシンポジゥム講演論文集, pp.141-146, 2001

［８］畦原宗之, 海老原祐, 鬼沢武久, “作り手のイメージ を反映させた楽曲生成システムに関する研究”, 感性 工学研究論文集, Vol.1, No.2, pp.66-72, 2001

[9] 芳村亮, 中西崇, 北川高嗣, “任意の言葉の印象と音 楽心理学に基づく楽曲自動生成方式”, 電子情報通信 学会 DEWS2007 A3-3, 2007

[10］水野正敏, “水野式音楽理論解体新書”, 株式会社シン コーミュージック・エンタテインメント, 2006

[11] K.Hevner, "Experession in music : Ad discussion of experimental studies and theories." Psychological Review. Vol.42, pp.186-204, 1935

[12] K.Hevner, "Experimental studies of the elements of expression in music.”American J.Psychology. Vol.48, pp.246-268, 1936

[13] K.Hevner, "The affective value of pitch and tempo in music.” American J.Psychology, Vol.49, pp.621-630, 1937

[14］中村均, “音楽の情動的性格の評定と音楽によって生 じる情動の評定の関係” 心理学研究, Vol.54, No.1, pp.54-57, 1983

［15］中村一男編，“反対語大辞典”，東京堂出版， 1965

[16] 坂本崇, 梶川嘉延, 野村康雄, “音楽感性空間におけ る非線形判別分析を用いた曲印象別グループの分割”, 情報処理学会論文誌 Vol.40，No.4 pp.1901-1909， 1999

(2009年 2 月25日 受付) (2009年 8 月 1 日 採録)

[問い合わせ先]

× 934-0293 富山県射水市海老江練合 1-2

富山商船高等専門学校

秋口 俊輔

TEL : 0766-86-5100

E-mail : akiguchi@toyama-cmt.ac.jp

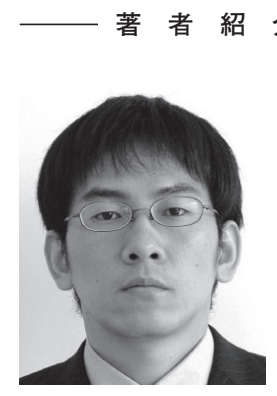

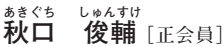

鳥取県出身。2001年大阪電気通信 大学情報工学部情報工学科卒業. 2003 年同大学院工学研究科修士課程 修了. 2007 年福井大学大学院工学研 究科博士後期課程修了. 現在, 富山商 船高等専門学校助教. 博士 (工学). 知 能ロボットの感情表現及び感性的創造 物の自動生成システムに関する研究に 従事. 日本知能情報ファジィ学会, 日 本感性工学会, 日本ロボット学会, バ イオメディカルファジィシステム学会 の会員. 


\section{Development of Melody Automatic Generation System from Music Impression Using Soft-Computing Method}

by

\section{Shunsuke AKIGUCHI}

\section{Abstract :}

It is still in the way to make music generation system which reflects human sensitivity in various research organizations. Among systems which are studied, there are typical systems such as the system which composite music from the impression of words and the system which utilize Genetic Algorithm. The purposes of this study are to compose several music, to cope with the sensitivity of each individual by visualizing the relationship between human sensitivity and musical structure, quantify the whole musical structure which decides the impression of music and to realize the construction of the automatic musical creation system which reflects individual sensitivity by the method of modeling the relationship of this structure and each individual sensitivity by Neural Network. First of all, a whole musical structure to decide its impression shall be quantified as musical structure element such as key, harmony, melody, and pitch as well as rhythm and tempo based on the idea,"Music is composed of three elements such as rhythm, melody, and harmony". Then, the relationship between music and impression felt from the music shall be replaced by the followings: the relationship between musical structure element quantified music and impression words quantified impression by SD method. Therefore, the relationship between music and its impression from music shall be learned. Secondly, the relationship between music acquired through learning and its impression shall be used to acquire musical structure element of impression levels to enter by Genetic Algorithm. This regards musical structure element as the individual of genetic algorithm. Therefore, this regards musical structure element as entries of learned Neural Network to output the value of musical impression of input music. To learn the difference between the value of musical impression obtained here and the value of musical impression to compose as assessment function automatically generates music of its impression.

Keywords : Soft-Computing, Melody Automatic Generation System, Human Simbiotic System

\section{Contact Address : Shunsuke AKIGUCHI}

Toyama National College of Maritime Technology

1- 2 Ebie-Neriya, Imizu, Toyama, JAPAN

TEL : 0766-86-5100

E-mail : akiguchi@toyama-cmt.ac.jp 